\title{
The challenges of contemporary wound care
}

\author{
Bill McGuiness
}

From Australasian Podiatry Council Conference 2011

Melbourne, Australia. 26-29 April 2011

Providing effective wound care to clients within the Australian context poses a number of challenges. For the clinician keeping abreast of continually changing arrays of products and supporting evidence is often daunting. For the client making sense of often conflicting advice and managing the personal costs of their treatment poses a significant challenge. For the health care provider providing efficient wound care within budgetary constraints is often difficult. Each of the above perspective is examined and practical solutions discussed in order to help improve contemporary wound management practices. Approaches to categorising wound management products will be presented as well as a list of user friendly resources that can be used by the clinician to judge their efficacy. Contemporary wound management techniques will be discussed with a focus on simple interventions that will help reduce delayed wound healing. The community awareness campaign being conducted by The Australian Wound Management Association will also be presented providing clinicians with possible avenues for further involvement.

Published: 20 May 2011

Submit your next manuscript to BioMed Central and take full advantage of:

- Convenient online submission

- Thorough peer review

- No space constraints or color figure charges

- Immediate publication on acceptance

- Inclusion in PubMed, CAS, Scopus and Google Scholar

- Research which is freely available for redistribution
C Biomed Central 